This item was submitted to Loughborough's Research Repository by the author.

Items in Figshare are protected by copyright, with all rights reserved, unless otherwise indicated.

\title{
Age matters: Encountering the dynamism of a child's agency from cradle to emerging adulthood
}

\section{PLEASE CITE THE PUBLISHED VERSION}

https://www.springer.com/gb/book/9783319897332

\section{PUBLISHER}

Springer

VERSION

AM (Accepted Manuscript)

\section{PUBLISHER STATEMENT}

This book chapter was published in the book Translocal Childhoods and Family Mobility in East and North Europe [@ Springer]. The publisher's website is at https://doi.org/10.1007/978-3-319-89734-9

\section{LICENCE}

CC BY-NC-ND 4.0

\section{REPOSITORY RECORD}

Lulle, Aija. 2018. "Age Matters: Encountering the Dynamism of a Child's Agency from Cradle to Emerging Adulthood”. Loughborough University. https://hdl.handle.net/2134/13103354.v1. 


\title{
Chapter 10. Age Matters: Encountering the Dynamism of a Child's Agency from Cradle to Emerging Adulthood
}

\author{
Aija Lulle \\ Accepted version. Full reference: Lulle, A. 'Age matters. (2018) Encountering dynamism of child's \\ agency from a cradle to emerging adulthood. In Assmuth, L. et al (eds) Translocal childhoods and \\ family mobility in East and North Europe, Palgrave, pp. 235-250
}

\section{Introduction: agency and growing bodies}

Throughout three years of fieldwork I kept in touch with my key participants on a regular basis. Looking back on my fieldwork in Finland, Latvia and the UK I had participants mothers - who were expecting children during our first encounters. I met and observed babies still in the crib, and toddlers just exploring the joy of walking and escaping from their mother and me - a newly met stranger to these children. My interactions included preschoolers and school-age children and interviews with young adults who told me about their childhood experiences. I witnessed children 'growing up' as we usually say about children in everyday language. But more to the point, I witnessed how I was growing along with children in my efforts to understand children's agency at different times and in different places of translocal childhood.

In a seminal paper titled "What is agency?" Emirbayer and Mische (1998, p. 963) argued that human agency is a temporally embedded process of social engagement. However, their theoretical architecture of agency was implicitly meant for 'adult studies'. Childhood studies have always emphasised the relevance of age: from 'early childhood' to 'middle childhood', from 'early' to 'late adolescence' and 'emerging adulthood' (for a useful overview of diverse approaches, see for example Qvortrup et al. 2009). In this chapter I bring the theoretical view of a temporary agency into dialogue with childhood studies. I argue that children's agency is also very much shaped by age, but not in a linear way. A child draws on different resources and accepts or transgresses different barriers while growing. A child also draws on bodily resources to cry, scream, resist. A child can use agency to stop speaking in one language but 
can also amplify his or her agency through multi-lingual skills. None of these are solely context-dependent but are geography dependent as well because children act differently in different places.

My overall aim is to provide nuances to the debate on how age matters in the research on childhood agency, sometimes through unexpected and surprising twists and turns. Young children who may not yet speak any language, have an embodied capacity to interrupt and significantly change ways in which we converse with parents and with other children. Preschoolers and other participants in their 'middle childhood' demonstrated considerable dynamism where embodiment and conversations shaped the ways that we see and understand the world. Young adults placed the main emphasis on narration and reflexivity, revealing childhood secrets that had to be kept 'silent' in rich worlds that are separate from adult lives. Understanding temporality gives us analytical strength as researchers. However, it also poses further challenges to how we capture and explain agency in specific situations, and to a how we understand the broader context of the translocal childhood as a life-course period.

Looking back at my fieldwork encounters I want to tease out some pertinent examples of how age mattered in terms of child's agency. In the remainder of this chapter I will provide brief insights into three broad groups of participant: (1) a younger group from birth to pre-school age, (2) a 'middle childhood' group, or early school children, (3) 'emerging adults', who talk about their childhoods, and (4) their adolescence experiences. But I will begin with the methodological aspects.

\section{Methodological view: Growing together with the research participants}

In terms of empirical material, I carried out fieldwork (2012-2014) at different sites, in Latvia, in Helsinki, Finland, and in London and Guernsey (UK). I had been working since 2010 for my doctoral research in the latter site. I also observed children's journeys across borders, travelling with children from Latvia to the UK and from Finland to Latvia. In Latvia I observed four families for several years, meeting with the children, usually in the summer. I also engaged in numerous shorter observations, one-off interviews with children and parents in my short-term fieldwork at summer places in Latvia, and in research participants' homes in 
Finland, Latvia and the UK. I also regularly went for walks and played outdoor with children. I used a voice recorder on many occasions, although sometimes these encounters lasted for almost a full day and I recorded or wrote down my fieldwork notes afterwards. I travelled by car with a child who travelled from Riga to visit his parents in Guernsey (2010), and several times with Latvian-Finnish children (2012-2014) across the Baltic Sea. I observed and noted in my diary multiple episodes when families with children travelled by air. All the interviews were given with explicit consent by parents and extended families. In addition, even during short observation episodes or encounters in public spaces I made clear to my interlocutors that I was working on long-term research into translocal families.

My data also consists of 10 in-depth interviews with young adults who had migration experiences to the UK or Finland, and in some cases, experiences involving several other countries, or who had returned to Latvia. Some of them were interviewed more than once, and participants were encouraged to narrate freely. These interviews lasted from two to sometimes more than four hours, and research participants were 19-27 years old at the time of interview.

In terms of methodological enquiry, I make use of the notion of 'age', but do not always use it in a strictly chronological way. However, for children themselves, chronological time can be extremely important, especially when they enact their agency and claim seniority over one another. This is also closely intertwined with schooling and the intensity of new knowledge they have obtained.

My enquiry involves broad notions of 'time', too. According to Emirbayer and Mische (1998, p. 963-964) agency 'is informed by the past' as our past has created habits, traditions and routines as well as being 'oriented toward the future' in as much as we imagine ourselves and others. We also compare ourselves to others who are living beside us or to people who have already achieved something that we want to achieve or consider to be an alternative possibility. In addition to this, agency is also oriented 'toward the present' as we contextualise our past and our imagined future from the vantage point of the present. I stay 
alert to these time notions too; but above all, agency is profoundly relational. A child has capacities to influence, shape and change the ways others live translocally.

\section{Travelling in a cradle, in a pram, on foot}

At interview, women who were either expecting a child or already had a toddler talked vividly about their wish to be closer to their own mothers (usually still living in Latvia) or to have health checks in Latvia due to their familiarity with the system. Thus, from a relational perspective, we can introduce the notion of agency even before one's individual life course begins because the unborn child influences the parent's translocal trajectories before birth.

Furthermore, when a child was born, the small body and face had its uniqueness. We introduced Agnija, a Latvian living in Finland in Chapter 3. When her daughter was born, Agnija looked into her face and felt that her daughter's name was Māra, a strong, historical Latvian name. A new-born has considerable agency that is somewhat overlooked in the individualised, adult views on translocal issues. A child needed a citizenship and travel documents in order to travel to relatives in Latvia for the first time (Latvia has officially allowed dual citizenship since 2013). If it is was difficult to obtain a Latvian passport for some reasons (for instance, there was no consulate in Guernsey; the closest one was in London), but a passport is urgently needed, children in several mixed families obtained only British passports to their children despite a wish to give a dual - also Latvian - citizenship.

According to my observation of toddlers, their agency was both embodied and voiced. A toddler or a small child of three to five years old can demonstrate a rich bodily 'language'. A small child can act impatiently wanting things immediately, and, if these things do not arrive or happen the child protests, expresses agency intensely with movements, facial expressions, a stiffening of the body (for example, so that she or he cannot be put into a pram), screaming. Toddlers explore space actively. For instance, when visiting Latvian relatives, my young participants were suddenly not in their own 'homes' and it took time to get used to different 
beds, doors, staircases. When travelling, young children can feel bored, wanting to play. Planes and airports can become places where children may feel constrained bodily, although young children, more easily than their older peers, subvert the rules that oblige passengers to be quiet. Trains are a better choice making moving around easier during the trip. Children's embodied capacities to shape adults' agendas are enormous, and, according to my observations, children often use embodied protest on to enact their agency.

One of the most important issues of translocal living was a question of language acquisition. Almost all parents felt sensitive when talking about the language skills of their young children. Even though I did not ask a question about language skills, sometimes parents were almost apologising that their children spoke little or no Latvian. I interpret this as a partly unconscious 'affect' of relations in families across borders. Moreover, my participants perceived the language issue as the choice of the parents, often informed by developmental psychology ideas of cognitive development in early childhood (for example Piaget 1972). Some parents spoke at length about their language teaching strategies. For instance, in England I met and observed twin boys since several times (meeting them first when they were 1.5 years old). The mother spoke Latvian to her boys but her English husband spoke English. During the next two summers the mother spoke only English to her children: she consulted with local English and migrant mothers and decided not to mix up languages. We met on one occasion during their summer in Latvia when the boys were 4.5 years old, and we conversed, crafted stories and sang together in English. The boys were curious to sprinkle in some Latvian words in their creative stories, thus signalling their capacity to rely on different linguistic resources. Some children use their passive agency - keeping silent, observing, refusing to speak (cf. Coe et al. 2011) even if they had been actively taught two languages by their parents. When relatives in Latvia asked something in Latvian, the children in this study responded in either English or Finnish.

In sum, a child's agency during the early childhood is mainly enacted translocally through the very existence of the child. When parents expect a new baby, new arrangements for living and visiting are planned; new political, ethnic and other identity markers are made through name-giving and acquisition of passports. Children use their bodies to express desires, 
protest, and to get used to new places and routines. Finally, children are exposed to several languages and start choosing when and how to respond, and in which language.

\section{Middle childhood, or young school-age children}

Children's lives in this age group are strongly shaped by school schedules and intense learning (see also chapters 7 and 10). However, bodily aspects to enacting agency are no less important. For instance, cousins who live in different places can 'flex' their agency through bodily encounters, for example by seeing who has grown stronger or taller. Agency is also enacted in relationships between children, where even small age differences are big due to growing bodies. Moreover, normative values enter into children's views more clearly and children quickly choose how to emphasise their wishes and their knowledge of values and norms. For instance, in most of the 'gentle encounters' (as Pihla Siim has titled her vignette in this book) - i.e. observing, with minimal intervention, children playing and talking among themselves - those children who live mainly in Finland or the UK did not stress gender differences, whereas their cousins and friends in Latvia were more aware of them and singled out 'girly' and 'boyish' things, colours and behaviours (cf. Halim and Ruble 2010). My participants from the UK and Finland were usually dressed more casually than their Latvian cousins and friends.

Bodily encounters are particularly important when a common language is lacking. Beate, aged seven at the time of the interview, remembered her first school day in England. Beate spoke almost no English other than a few greeting phrases. But she used her fingers, her body language, her eyes and details of her clothing to make contact and forge a potential friendship at a new school:

I remember that I was in the school. I met my first friend, a girl. It was at lunchtime, we had to eat what we had in our lunchboxes. I saw a girl form my class. I asked what her name in English was, and I enacted a funny game. She had lovely embroidery [a little 
cross] on her jumper and I had one on mine, too. But her embroidery was a bit different than mine. I said: "Hi, that's mine." And she smiled back and pointed to my cross and said: "Hi, this is mine." The teacher saw us playing, she smiled, and came to us. And then she asked my name and I answered (Girl, 7).

Beate was a talkative, confident participant. She relied on her other resources to meet the challenging situation in her new school in London. This is why her recent memories where positive and she embraced new opportunities eagerly. She happily explained that the teacher did not make a big deal about her not speaking English. The teacher took her by the hand, smiled to the class and said: "We have a new child." Beate picked up language skills quickly and taught her mother her newly acquired English phrases as they walked home. Beate was also fluent and artistic in her Latvian expressions with me, a Latvian-speaking stranger in London. She enjoyed being the centre of attention in our interviews. Here I can draw on Ní Laoire et al. (2011) and Tyrrell (2015) on how children recognise the roles and statuses they are assigned in various places and at various times.

Language-wise, translocal childhoods are diverse, as are the diverse agentic strategies used by children (Qvortrup 2005). While Beate embraced English happily, and simultaneously developed her Latvian language resources through her own preferences and wishes, other children opted to speak in one language. For instance, a girl the same age as Beate, whom I met in Guernsey, did not speak English at all when she first arrived. After a year, she spoke English, and passively understood Latvian. But by the third year she was saying that she was an English girl, and proudly showed her study achievements. During their schooling, age matters a lot to children: their bodies grow and they learn many new disciplines, including foreign languages. It was at during the middle childhood period when some of my participants' friends and cousins across borders began mixing in English words that they had come across at school, or through their consumption of globally available culture brought to them through the media.

\section{Adolescence remembered and assessed}


Throughout childhood and adolescence it is not only language ability that develops and deepens; adolescents might also choose not to use their language, i.e. not to talk, which also acts as a form of protest crucial to their agency. In comparison with children, young adults as narrators of their childhoods have the specific advantage of distance to events in their lives. Evaluations of their agency during their teenage years can differ considerably. Distressing situations can now be evaluated as humorous, as character building events of agentic power, or vice versa, childhood efforts, which then seemed almost heroic might have little value or even a negative influence from today's point of view. Apart from this, the formal transition to legal independence (coming of age at 18) was particularly liberating for young people. Particular empowering agentic strategies that were used to overcome difficulties were evaluated from the current viewpoint.

One of my adult participants, Kate (aged 20 at the time of the interview) was 11 years old when her parents divorced. Her stepmother told Kate that her mum left her behind because she did not want take care of her:

I was just a child [when my mother left for England]. When you hear such things about your mother constantly, it creates a barrier. I had a bit of anger, resentment towards my mum. I did not get on well with my stepmother... When aged 16, as I was [during the last year before moving to England], there are many girls' issues and you want to talk about these with your real mother, not with your stepmother. But my mum was at work and worked many hours in factories where she worked all these years. When she was at work it was not really possible for her to pick up the phone or call me back. I was also nagging at my mother, like 'Why do you not want me? Why do you not take me to England? (Kate)

Kate's story reminds us how constrained a child' s agency is: laws, informal regulations, familial relations in different localities are all obstacles a child must deal with using only their capacity to question, to demand, to cry, to protest against parental decisions. In Kate's example we can see how she was crafting her agency based on social ideals of what a mother 
should do for her daughter, specifically provide hands-on care. Moreover, Kate particularly emphasised her teenage needs and "girls' issues", which added to her anger and critical attitudes towards her absent mother. However, during the interview, as an adult she also displays a more sensitive understanding of how messy family lives can be. The very notion of the idealised 'family' must be critically questioned in translocal settings. A 'real life' family across borders includes not only separated parents but also spouses and all the complexities that come through dynamic family change and children's changing needs and affections.

I would like to emphasise the issue of a child's agency in relation to responsibility using another example of remembered adolescence. Children need to keep silent about any adult jobs or tasks that they undertake because of normative shaming for un-childlike duties (Aitken 2001). In migration contexts such tasks are often related to translation for parents (children are included in the school system and pick up the new language more quickly). But in emigration contexts, and more specifically in cases where children are left in Latvia alone or under the auspices of relatives or close friends, such responsibilities are centrally related to money issues. Children have to learn to deal with money issues more quickly than those whose parents provide money for the family budget. I interviewed Inga several times, 19-20 at the time of the interviews in Riga. She had been living with her grandmother for some years while her mum was working in Riga; she had also lived alone for periods during her teenage years while the mother was abroad. In a sense, children like Inga become independent more quickly than their peers. She was 14 when her mother went abroad for another two months leaving her fully responsible for an apartment and all the daily chores. Inga continues:

But it was great - being at home alone and understanding how to do chores. I had choices, I could have gone to my grandparents in the countryside, but then again it was a school time and I could not really be away for so long. I had to calculate everything, how to spend money, which food to buy. All the rest of the household things. But I was already quite independent from early childhood as my mum always had her millions of jobs to manage. Mum left some money, it was calculated to be enough for two months, but then again it did not cover some unexpected needs. Then 
I went to my aunt [in a nearby town, $40 \mathrm{~km}$ away], my mum transferred money to her account and this is how I managed. (Inga, 20)

Inga, an emerging independent adult, spoke freely about her empowering experience and how she was able to enact her agency and find solutions. But back in her teenage years it had been important not to tell such life arrangements to strangers. Translocal living and extra trust given to a teenager had to stay strictly in close family circles. Had it been known to state representatives or schoolteachers, Inga's mother might have been punished for not providing daily care for her teenage child. It had to remain a secret precisely because of the child's age. "Only my closest friends knew that I was alone for those two months," Inga told me. Later on at the age of 15 Inga went to a vocational school, but by then her mother was expecting another child:

I was very happy, and my mother was even happier. But then again I was thinking - I am 16, I am about to begin my own life but I am bounded again because I need to look after my small brother. (Inga, 20)

Punch (2002) has demonstrated how independence for a child is a 'negotiated phenomenon'. Inga was about to launch her independent life, go and live in a dormitory at the vocational school, but a new child in her family meant that as a responsible teenager she had to help her mother with childcare. Although Inga could have insisted on her egoistic 'independence', instead she emphasised responsible 'interdependence', or, to put it in Nyberg-Sørensen's (2012) words, a 'co-opted agency' where her mother's happiness and their new family meant that Inga enacted her agency as both a student and an older sister.

\section{Young adults 'travel' back to childhood, and to an imagined future}

In this last empirical section of age matters, I will look at one example of an 'emerging adult' (Jensen 2007). 'Emerging adulthood' as a term is increasingly used to describe age from the late teens to mid- to late $20 \mathrm{~s}$ in industrialised societies. Youth moves towards an independent 
life and adulthood, although this period in life is still 'youthfully' different from the later characteristics of full adulthood and its responsibilities. Adulthood emerges differently in translocal lives. The geographical aspect of where I lived before, and where I wish to live my adult life, is more prominent compared to peers who never emigrated.

Childhood memories are told and revised, and translocal experiences also shape future imaginations in terms of where a person wishes to live (cf. Philo 2003). Let us see these temporalities of past, present and future in a narrative from Roberts, whom I interviewed twice, once in Latvia and once in the UK. Roberts was a 10-year-old boy when his parents took him with them to live in a city in northern England. Before that he lived for a year with his grandparents while his mum and dad were settling in the UK. He originally comes from the eastern part of Latvia where many, including Roberts' family, speak the Latgalian dialect that is distinct from standard Latvian.

I was very excited because I thought we were moving to London. From what you see from the TV I associated London with Mr Bean. But at the same time I was sad because I had to leave my grandparents. It was the separation of our family that scared me, but I was always one of those kids who wants to explore the world and experience different things; while in Latgale I had very little to do.

In Latvian schools there were many more demands put on the pupil. In the UK I had no homework at all and everything was relaxed. That was a very shocking cultural experience because I thought 'wow, in Latvia they really put pressure on us!' My parents were not happy that I didn't have any homework because they believed that a good education means a lot of homework. 'You've got to study a lot to become somebody,' they told me. Also moving from a fairly small town in Latvia to a pretty big town in the UK was very interesting because you could see the diversity...

Here [in England] I realised how much I care about Latvia and Latvians. Being away from Latvia made me want to study something that would help me if I return to Latvia and help me improve the society in at least some way. The UK has given 
me a lot of opportunities to learn and see things from a different perspective. (Roberts, 21)

See how Roberts' narrative flows translocally: his story 'travels' from his Latvian (national/state) affiliation to his native regional, Latgalian, specificity, language influences, and to his childhood imagination that the UK meant London. Very often translocal children come from rural environments in a different country and go to urban milieus (Hörschelmann and Schäfer 2005). Note, how 'excited' Roberts was, how he reflected on his own 'wow' experience of the lack of homework in the UK and of his parents' shock and belief that only through studying hard could their son become 'somebody'. Roberts' parents believed in the virtue of loads of homework, based on their experience of a different schooling system during the Soviet period.

Roberts is an accomplished young man (aged 20 to 22 at the time of the interviews) with shining higher education diplomas from the UK. Moreover, as a bright young man with a university degree and a privileged European Union Latvian passport, which allows him to travel easily within Europe, not only has he visited Latvia many times, he has also managed to obtain voluntary summer work in Latvia and contemplates his potential intellectual 'investment' in Latvian development. His story is not just memory: Roberts narrated his childhood agency from today's point of view. His agency is fundamentally relational influencing how he acts, reacts and changes in relation to other people and places. His agency is also distributed in space and time - he was unable to do many things in provincial Latgale, while he was 'excited' about and grateful for the resources and opportunities he could access in the UK. His capacity for hope and excitement, and his ability to envisage the future were all crucial elements of his child's agency.

\section{Discussion}

In translocal contexts, a child's agency is crafted in dynamic relations between people and places. Children grow, and meeting up with relatives and acquaintances across borders is 
often accompanied by the exclamation: "Oh, how you have grown!" Children move from place to place, while at the same time the places where they grow change (Prout 2000). In addition to these dynamics I argue that children have considerable capabilities to influence and shape adult trajectories.

The way that children enact their agency is relative to their biological and social capabilities. This is, crucially, a temporally embedded process of social engagement (Emirbayer and Mische 1998), although in specific ways it is characteristic of social norms, expectations and schooling systems. Children in their translocal movements are knowledgeable, learning subjects. This includes learning social norms and responding to expectations in different places and social relations, and developing meaningful practices within both migratory formal institutions and informal relationships. Thus, the child's agency is both being, and a process of becoming (Valentine 2003; Horton and Kraftl 2006; Worth 2009). Moreover, biological, cognitive, social aspects of language play an important and specific role in translocal life courses.

In 'early childhood' the embodied capability to enact one's own wish is very important, as is the exploration of various places in different countries. If we see agency as relational shaped by time and space, and by human relations - we could even put forward the idea that an unborn child has agency. Similarly, a new-born child's face and body may have agency. But such agency is not individual: it can be crafted in the intimately intense moments in which a mother looks at her child and decides to give it her name from her extended family, which lives in another country. The language abilities and preferences in 'early childhood' seem to be strongly influenced by parental strategies. I remember a mother in England who told me about her new-born baby in our first interview, about her Latvian visits in the next interview, and my own encounter with her child in one of the plane journeys. The child was a curious, smiling girl eager to interact with me; the mother shyly said that I can talk to her daughter in Latvian but that she would respond in English. Thus, I agree that childhood agency is constrained, certainly when it comes to choices on which language the child wants to learn in early childhood. Cati Coe, along with her co-authors, has suggested that children's agency can be defined as "the ability to express their will and to act, these capabilities include a child's personality, independence, autonomy, and a creativity dimension" (Coe et al., 2011 
p. 7). However, there are caveats. Child agency is also substantially restricted by legislation, social structures and education institutions (Vanderbeck 2008; Coe et al. 2011 pp. 8-9; Baldassar et al. 2014).

Language-wise, childhood agency during 'middle childhood' is also restricted by school systems and family preferences. Age matters more here every year as children learn intensely while their bodies develop. They also flex their agency in bodily encounters when meeting relatives and friends across borders, claiming to be 'bigger, older, stronger' or, conversely, claiming protection and kindness because they are younger.

From 'early' to 'late adolescence' and 'emerging adulthood', various school systems continue to shape children's agentic potential. What matters most translocally is the will of children, which they begin to demonstrate in relation to belonging and their (non)willingness to keep in touch with extended family elsewhere. The teenage years might become a time when children more categorically reproach their parents for their migration choices. Some teens may refuse to visit Latvia because all their immediate friends and hobbies are now abroad. Others, in contrast, may particularly seek to underline their dual belonging and nurture contacts with Latvian relatives and friends.

In summing up, we can say that time and space is constitutive of a child's agency translocally, although agentic capabilities and opportunities are unevenly distributed throughout the life course. These capabilities are embodied, cognitive, social and linguistic and include more subtle and diverse capabilities that are specifically shaped by translocal living. Children are physically and mentally 'growing up' as we usually say about children in everyday language. However, this does not mean that a small child has less agency, rather that agency increases gradually with age. Agentic capabilities take surprising twists and turns. A small child can have a significant influence on adults' translocal trajectories, while different teenagers may feel either severely constrained or liberated by the structural arrangements of translocal living. Last but not least, children 'grow' along with the changing environments around them, and adults, such as researchers, must 'grow' with the children in a continuous effort to understand child agency at the different times and in the different spaces of childhood. 


\section{References}

Aitken, Stuart.C. 2001. "Global crises of childhood: rights, justice and the unchildlike child" Area 33, 119-27.

Baldassar, Loretta, Kilkey, M., Merla, Laura and Wilding, R. 2014. "Transnational families". In: The Wiley Blackwell Companion to the Sociology of Families. First Edition. Edited by Judith Treas, Jacqueline Scott and Martin Richards, 151-197.

Coe, Cati, Reynolds, Rachel R., Boehm, Deborah A., Hess, Julia Meredith and RaeEspinoza, Heather. 2011. Everyday Ruptures: Children, Youth, and Migration in Global Perspective. Nashville: Vanderbilt.

Emirbayer, Mustafa, Mische Ann. 1998. "What is agency?” American Journal of Sociology, 103(4): 962-1023.

Halim, Ling May and Ruble, Diane. 2010. Handbook of Gender Research in Psychology pp $495-525$

Holloway, S and Valentine, Gill. 2000. "Corked hats and coronation street: British and New Zealand children's imaginative geographies of the other". Childhood, 7(3): 335-57.

Hörschelmann, Kathrin and Schäfer, Nadine. 2005. "Performing the global through the localglobalisation and individualisation in the spatial practices of young East Germans". Children's Geographies, 3(2): 219-242.

Hörschelmann, Kathrin. 2011. "Theorising life transitions: Geographical perspectives". Area, $43,378-383$.

Horton, John and Kraftl, Peter. 2006. "Not just growing up, but going on: materials, spacings, bodies, situations". Children's Geographies, 4: 259-276.

Jensen, Arnett, Jeffrey. 2007. Emerging Adulthood: What Is It, and What Is It Good For? Child Development Perspectives, 1 (2): 68-73 
Moskal, Marta. 2015. “"When I think home I think family here and there': translocal and social ideas of home in narratives of migrant children and young people". Geoforum, 58:143-152.

Ni Laoire, Cati, Carpena-Mendez, Fina, Tyrrell, Naomi and White, Allen. 2011. Childhood and migration in Europe. Portraits of mobility, identity and belonging in contemporary Ireland. London: Ashgate.

Nyberg-Sørensen, Ninna. 2012. "Revisiting the Migration-Development Nexus: From Social Networks and Remittances to Markets for Migration Control”. International Migration, $50(3), 61-76$.

Philo, Chris. 2003: 'To go back up the side hill': memories, imaginations and reveries of childhood. Children's Geographies 1, 7-23.

Piaget, Jean. 1972. The principles of genetic epistemology. Routledge and Kegan Paul, London.

Prout, Alan. 2000. "Childhood bodies: construction, agency and hybridity". In Prout Alan (ed.) The Body, Childhood and Society. Macmillan, Basingstoke: 1-18.

Punch, Samantha 2002. "Youth transitions and interdependent adult-child relationships in rural Bolivia”. Journal of Rural Studies 18: 123-33

Qvortrup, Jens, Corsaro, William A., Honig, Michael-Sebastien (eds). 2009. The Palgrave Handbook of Childhood Studies. Basingstoke: Palgrave Macmillan

Qvortrup, Jens. 2005. "Varieties of childhood”. In Qvortrup, Jens. (ed.), Studies in modern childhood: society, agency, culture, Basingstoke: Palgrave Macmillan, pp. 1-20.

Tyrrell, Naomi (2015) “Transnational migrant children's language Practices in translocal Spaces". In: Diskurs Kindheits- und Jugendforschung 10(1): 11-23. http://nbnresolving.de/urn:nbn:de:0168-ssoar-439330

Valentine, Gill. 2003. "Boundary crossings: transitions from childhood to adulthood". Children's Geographies, 1: 37-52.

Worth, Nancy. 2009. "Understanding youth transition as becoming: identity, time and futurity". Geoforum, 40(6): 1050-1060. 
